\title{
Visual dysfunction in Huntington's Disease: a systematic review
}

Amit Dhalla $^{1 *}$, Susil Pallikadavath ${ }^{1 *}$, and Claire V. Hutchinson ${ }^{2}$

${ }^{1}$ School of Medicine, College of Life Sciences, University of Leicester, Leicester. UK

2 Department of Neuroscience, Psychology and Behaviour, College of Life Sciences, University of Leicester, Leicester. UK

* Denotes joint first authorship

Running head: Vision in Huntington's Disease

Correspondence:

Claire V. Hutchinson

Department of Neuroscience, Psychology and Behaviour, College of Life Sciences, University of Leicester, Leicester. UK. LE1 7RH

Telephone: +44 (0)116 2297183

Email: ch190@le.ac.uk

Key words: Huntington's Disease; vision; the retina, visual pathways, primary visual cortex; colour vision, contrast sensitivity, motion perception 


\begin{abstract}
It is well-documented that patients with Huntington's Disease exhibit specific deficits in visual cognition. A less well-documented literature also exists that suggests people with Huntington's Disease experience a number of disease-related changes to more rudimentary sensory visual processing. Here, we review evidence for the effects of Huntington's Disease on the integrity of the early visual pathways in humans along with changes to low-level visual sensitivity. We find evidence for reduced structural and functional integrity of the visual pathways, marked by retinal thinning, reduced VEP amplitude, and cell loss and thinning in visual cortex. We also find evidence of visual perceptual deficits, particularly for colour and motion. We suggest that future studies with well-defined HD and HD-related groups in appropriate numbers that systematically examine the relationship between structural changes to the visual system, basic visual perceptual deficits and disease stage/severity are therefore likely to yield promising results.
\end{abstract}




\section{Introduction}

Huntington's Disease (HD) is a progressive neurodegenerative condition caused by an expanded CAG repeat in the huntingtin gene, which encodes an abnormally long polyglutamine repeat in the huntingtin protein [1]. Inherited as an autosomal dominant trait, each child of an affected parent has a 50\% risk of carrying the gene mutation. Core symptoms include motor problems, psychiatric disturbances and cognitive deficits. Symptom onset typically occurs between 30 and 50 years. There is no cure and the disease is fatal [2]. Motor symptoms represent the most outwardly distinct symptoms and are marked by chorea, dystonia, bradykinesia and akinesia [3]. Psychiatric symptoms often manifest in the early stages of the disease, prior to the onset of motor symptoms and include depression, anxiety, impulsivity, and irritability, which can be accompanied by aggressiveness and obsessivecompulsive behaviour [3]. Cognitive symptoms such as poor executive control and working memory deficits are also common and can be evident at least 15 years before diagnosis [4]. Predictive genetic testing is now readily available for at-risk individuals. However, a genetic diagnosis gives no indication of an individual's clinical state at the time of testing or when symptoms will become apparent [5]. Clinical diagnosis of manifest HD is typically made using the Unified Huntington Disease Rating Scale (UHDRS) which assesses motor function, cognitive function, behavioural abnormalities, and functional capacity [6].

Cognitive deficits represent a core feature of Huntington's Disease and the majority of tests used to assess cognition rely on visual representations of objects. As such, deficits in 'higherlevel' visual functions that require cognitive control are consistently documented. These include deficits in visual search [7, 8], visual selective attention [9], mental rotation $[8,10]$ and some aspects of visuo-spatial working memory $[7,11]$. In such cases, it is difficult to tease the relative contributions of reduced bottom-up, sensory neurotransmission and topdown cognitive control to performance impairments, although it is likely that cognitive disturbances have a marked effect on performance on some visual sensory tasks.

Deficits in oculomotor control may also impact upon performance on some visual sensory and/or visuo-cognitive tasks, particularly tasks that require eye-movement driven aspects of visual attention. Principal eye movement disturbances include impaired saccade initiation, reduced saccade velocity, increased saccade latencies, an increase in square-wave jerks and 
increased distractibility when required to fixate a single point. These oculomotor disturbances are pronounced in HD manifest patients and there is also evidence that they are also present, albeit to a lesser extent, in pre-manifest HD. ${ }^{1}$

Although deficits in visual cognition and eye movement control are typically regarded as the principal vision-related dysfunctions in HD, there is a parallel, somewhat disregarded literature concerning its effects on more basic visual perceptual processing. Here, we review the effects of this neurodegenerative disease on the integrity of the early visual pathways and the associated visual perceptual changes in humans.

\section{Materials and Methods}

A search was undertaken using Web of Science from January 1980 to May 2018, using the following search terms: "Huntington's”, 'visual', “vision”, "visual acuity”, “contrast sensitivity", “depth", "stereo", “colour vision", "form perception", "motion”, "retina”, "visual cortex". 26 articles were ultimately included in the review, identified in accordance with PRISMA guidelines [15] as summarised in Figure 1.

\section{Results}

\section{Changes to the integrity of the visual pathways}

A number of studies have reported HD-related effects on the structural and functional integrity of the visual pathways, where changes have been documented in the retina and in visual cortical areas.

The retina

Until recently, very few studies had assessed the effects of Huntington's Disease on the human retina. An early study reported that HD patients had higher increment detection thresholds for a foveal blue test than controls [16]. More recently, two studies have examined the possible effects of HD on the retina using electroretinograms (ERGs). Pearl et al. [17]

\footnotetext{
${ }^{1}$ Eye movement dysfunction is beyond the scope of this review and is comprehensively reviewed elsewhere $[12,13,14]$
} 
reported increased ERG amplitudes across a range flash intensities but there no differences in their latency. Conversely, Knapp et al. [18] reported reduced ERG amplitudes in single case study of a 25 year old asymptomatic gene carrier with no differences in latencies.

Comparable results were also reported for multifocal electroretinogram (mfERG) where P1 amplitudes were reduced in both eyes in the central retina whereas latencies appeared normal. Although Knapp et al. [18] report findings from a single case study, it is of note that reduced ERG amplitudes are in keeping with results from mouse models of Huntington's Disease [19]. Moreover, a key difference between the two studies is that whereas Knapp et al. [18] report data from an unmedicated premanifest subject, Pearl et al. [17] report data from a group of HD-manifest patients. Some medications prescribed to HD patients, such as haloperidol have been shown to enhance ERG amplitudes in non-human primates, causing them to appear normal [20]. As such, these findings may be due, at least in part, to medication rather than the disease per se.

A number of recent studies have used high-resolution retinal imaging techniques such as optical coherence tomography and have begun to uncover HD-related changes to the morphology of the retina. Temporal retinal nerve fibre layer (RNFL) thickness has been shown to be significantly lower in an HD group where both manifest and pre-manifest patients differ significantly from controls [21]. Within the HD group, there was no difference between manifest and pre-manifest HD. Although there was no overall significant difference in macular volume between the HD group and controls, decreased macular volume in HD patients was associated with increasing disease duration and there was a negative correlation between macular volume and motor scores (determined by the Total Motor Score of the Unified Huntington's Disease Rating Scale (TMS-UHDRS) [22]. Reduced macular choroidal thickness in HD patients compared to controls has also been reported [23]. Furthermore, although there was no significant difference in macular retinal thickness measurements between the HD and control eyes, in HD patients, there was a negative association between macular retinal thickness and motor scores on the TMS-UHDRS. More recently, reduced temporal, inferotemporal and superotemporal RNFL thickness, increased nuclear and outer retinal layer thickness and lower inner plexiform layer, retinal pigment epithelium and outer macular volume has been documented in HD compared to controls [24]. A number of correlations with indicators of disease progression were also reported. Of particular note were associations between mRNFL and ganglion cell layer thinning and disease progression. Finally, a single case study of an asymptomatic gene carrier found no 
evidence of any macular changes using OCT [18]. Additional details of retinal studies and their findings are summarised in Table 1.

\section{Visual evoked potentials}

Visual evoked potentials (VEPs) are electrical potentials, elicited by the brief presentation of visual stimuli. They are recorded from the scalp overlying the occipital lobe (visual cortex) and provide a measure the functional integrity of the visual pathways [25] in that they measure the amplitude (strength) and latency (timing) of visual system responses. A number of early studies examined the effects of HD on visual processing using visual evoked potentials (VEPs), the results of which are relatively conclusive [26-30]. The amplitude of VEPs were consistently reduced in HD patients compared to controls [29-30]. VEP amplitude was typically normal in at risk offspring of HD patients [26, 29], although there was a reduction in a subset of some offspring [27]. VEP latency was unaffected, being normal in patients and their offspring [26-30]. Further study details are provided in Table 2.

These early studies that assessed the effects of HD on VEPs were conducted before routine genetic testing for the disease. As such, whether at risk offspring had actually inherited the disease would have been unknown. Furthermore, although VEP studies provide useful insights into changes in the functional integrity of the visual system, abnormal VEPs can reflect changes anywhere between the retina and the visual cortex. However, it is worth noting that reduced VEP amplitude, as shown consistently in HD, is characteristic of optic nerve atrophy [31], a notion supported by recent findings from OCT studies for temporal RNFL thinning $[21,24]$ which suggest optic nerve axonal damage.

\section{Visual cortex}

Magnetic resonance imaging studies have revealed occipital atrophy in HD and premanifest $\mathrm{HD}$, particularly in occipitolateral, occipitotemporal and lingual regions [8, 32-36]. Additionally, there appear to be associations between visual cortical thickness and visuocognitive task performance $[8,35,36]$ and disease burden [36]. HD-related reductions in cell number in visual cortex have also been reported, although the precise nature and extent of damage in early visual cortical regions remains unresolved. An early study reported a reduction in cell numbers in BA17/V1 in the post-mortem brains of 5 advanced HD patients compared to 5 age and sex-matched controls have been reported [37]. More recent studies have shown some similar results where, although the extent of cell loss varied considerably 
within and between HD brains, widespread cell loss was identified for neurons and pyramidal cells in the parietal, temporal, and occipital lobes of 14 HD patients and 15 controls [38]. Although this pattern was least marked in primary visual cortex, it is of note that cell loss in primary and secondary visual cortices was associated with Huntington's disease motor symptom profiles. Other studies have shown cell loss in the primary visual cortex of 7 HD patients compared to 7 controls, where a 32 percent reduction in the estimated absolute number of BA17/V1 nerve cell numbers has been documented [39].

\section{Changes to visual sensitivity}

That effects of HD on the integrity of the visual pathways, particularly the retina and the visual cortex, are such that it is likely that there exist HD-related changes to basic visual function. Indeed, this seems to be the case whereby problems encoding both spatial (stationary) and temporal (moving) visual patterns have been reported. Below, we summarise these changes to basic visual function and, where possible, attempt to map such changes onto HD-related visual pathway damage.

\section{Colour vision}

Acquired colour vision deficits are common in neurodegenerative disorders and reflect damage to the retina and/or the optic nerve. Performance on the Ishihara Colour Plate Test, a test for red-green colour deficiencies, has been found to be compromised in HD [21, 24]. HD patients have also been shown to exhibit significantly worse colour/hue discrimination on the Farnsworth Maunsell 100 Hue Test, a chromatic discrimination test based on coloured capsorting. Deficits were characterised by greater total error scores (poorer overall colour discrimination) and partial scores on both red-green and blue-yellow axes [40]. Further details are given in Table 3.

The deleterious effects of HD on colour vision [21, 24, 40], particularly the reduced ability to discriminate between different hues [40], adds weight to the findings of ERG and OCT studies and to the notion that HD affects the retina and the optic nerve. However, mapping colour vision deficiencies onto specific HD-related pathology in the visual system is not possible based on the existing literature. For example, whether colour vision deficiency is congenital or acquired in HD patients is not clear, although it is likely that it is acquired. 
Acquired blue-yellow deficits that precede red-green anomalies are often indicative of retinal disease, whereas red-green deficits, which may be accompanied by some blue-yellow loss, are more likely to reflect damage to the retinostriate pathway (including the optic nerve) (Kollner's rule). However, there are examples of many ocular diseases that violate this assumption [41]. As such, although colour vision deficits may represent visual markers of HD, their clinical/diagnostic utility are, at present, unknown. For example, whether they are present in pre-manifest HD is presently unclear because only 6 pre-manifest patients have been included in one study [21]. In that study, there was no difference between pre-manifest HD and HD patients. Given the small number of participants, no firm conclusions can be drawn at present. There are also no longitudinal studies to determine the precise nature or time-course of colour vision deficits. Another cautionary note concerns recent findings that FM100 performance is not purely a measure of colour discrimination but instead also reflects general nonverbal ability [42]. Given evidence that non-verbal fluency is reduced even in prodromal HD [43], the FM100 may not represent a suitable means of testing colour discrimination in this group.

Form perception

Studies that have investigated the effects of HD on form perception (the ability to recognise and distinguish between objects) have investigated both simple, low-level visual discrimination and those that require higher levels of cognitive control. Deficits in higher level tasks that require the ability to spatially manipulate visual information (e.g. mental rotation) are consistently impaired in pre-manifest and manifest HD [8, 10]. However, these deficits are likely to reflect deficits in cognitive control, rather than deficits in visual function per se. The effects of HD on the ability to make simple visual form judgements remains unresolved. Whilst some studies report that the ability to distinguish between simple shapes is preserved in HD [44], others report that it is deleteriously affected [45].

\section{Spatial contrast sensitivity}

A number of studies have sought to determine the effects of HD on spatial contrast sensitivity. Contrast sensitivity refers to the ability to distinguish low contrast objects from each other and from their background. Contrast sensitivity deficits can be present even when there is no detectable impairment in visual acuity and can reveal abnormal visual processing 
at the level of the retina and in the cortical and subcortical visual pathways [46]. Studies that have examined spatial contrast sensitivity have done so using the Vistech Contrast Test System and psychophysical contrast thresholding procedures. The Vistech Contrast Test System is a contrast sensitivity chart made up of 5 rows of gratings depicting spatial frequencies of 1.5, 3, 6, 12, 18 cycles per degree of visual angle (c/deg) (top to bottom). Grating contrast (9 levels) decreases along each row (from left to right). Observers judge the orientation of each grating pattern (left, right, vertical). The lowest contrast grating for which the orientation is correctly identified determines the contrast sensitivity score. Psychophysical contrast thresholding procedures use carefully-controlled computer-generated sinusoidal grating patterns, across a range of spatial frequencies. Contrast thresholds correspond to the minimum difference between the light and dark transition at a border or an edge of a pattern or object that allows an individual to reliably detect its presence. Psychophysical techniques therefore provide a more sensitive measure of contrast detection than contrast charts. Contrast sensitivity has been determined in HD patients and HD gene carriers using both The Vistech Contrast Test System [47, 48] and psychophysical contrast thresholding techniques [44, 49] and no evidence of spatial contrast sensitivity deficits have been found (Table 3).

\section{Temporal contrast sensitivity}

Temporal contrast sensitivity deficits are often heralded as a means to uncover visual pathway-specific damage. For example, deficits that are most pronounced at low spatial and/or high temporal frequencies are typically regarded as reflecting a magnocellular problem, affecting magnocellular neurons that project preferentially to the dorsal visual stream. Those that are most pronounced at high spatial and/or low temporal frequencies are typically regarded as reflecting a parvocellular problem, affecting parvocellular neurons that project preferentially to ventral visual stream structures (although see [50] for a review). A single study has examined the effects of HD on contrast sensitivity for moving test patterns [44]. Participants judged the direction (left vs. right) of $1.3 \mathrm{c} / \mathrm{deg}$ sinusoidal grating patterns drifting at $2.1,9.3$ or $18.8 \mathrm{~Hz}$. Temporal contrast sensitivity was markedly reduced in patients compared to both a group of pre-diagnostic gene carriers with mild neurological abnormalities and controls at all temporal frequencies. Some temporal-frequency selective differences were also evident between groups (see Table 3 for further details). These deficits are likely to reflect changes in the local motion, contrast-sensitive stage of the motion processing pathway, typically associated with primary visual cortex (area V1). Future studies should examine a wider range of spatial and temporal frequencies, which may reveal a more 
detailed understanding of the spatiotemporal frequency-specificity of contrast sensitivity deficits and provide greater insight into the underlying disease-related pathology in the visual system.

\section{Global motion perception}

Global motion refers to instances in which the individual motion trajectories of local elements combine to create a larger aggregate moving stimulus. Although the local (individual) moving elements move along different trajectories, their combined direction appears to move coherently. Real world examples include the movement of a swarm of bees or a flock of birds. This type of motion can be simulated using random dot kinematogram (RDK) patterns in which some individual dots move in the same direction (signal dots) whilst others move randomly (noise dots). The greater the proportion of individual dots that move in the same direction (signal) and/or the fewer dots that move randomly (noise), the easier it is to judge the motion of the overall pattern. Two studies have investigated the effects of HD on global motion perception but have produced mixed results. One study [49] showed HDrelated deficits in the ability to accurately determine the overall direction of RDK patterns. This was reflected in lower noise thresholds for HD patients compared to controls (i.e., the proportion of noise dots, relative to signal dots, required to impair performance was significantly less in HD). However, a later study by the same group [44] found no differences HD and controls. The authors suggest that the differences between studies is most likely caused by differences in severity between the HD patient samples in the 2 studies, specifically, that participants in their earlier study were in the later stages of the disease. It is certainly plausible that this is the case. Differences in RDK stimulus parameters might also feasibly contribute to the disparity between studies. In other groups such as the aged, for whom global motion perception is differentially compromised, deficits are specific to particular stimulus parameters, such as the contrast, spatial displacement, or speed of local moving elements [52]. Future studies are therefore required to determine the precise nature and extent of global motion deficits in HD and HD-related samples.

Global motion processing deficits reflect damage to the extrastriate areas of the dorsal visual processing stream (e.g. MT, MSTd) in which the output of local motion detectors earlier in the motion processing pathway (e.g. V1) are pooled or combined [51]. If reliably established, deficits in in this domain would indicate degraded output of local motion detectors early in cortical visual processing pathway (e.g. V1), a reduced ability of neurons in extrastriate 
visual areas (e.g. MT) to integrate/pool the output of local motion detectors across visual space, or a combination of both. Of particular note is that motion processing deficits fit well with reports of cell loss in layers IVc and VI of BA17/V1 [39], both of which have been implicated in transmitting neural signals concerning visual motion up-stream from area V1 to extrastriate visual areas such as MT, via the magnocellular processing stream [53].

\section{Summary and conclusions}

In recent years, genetic testing has allowed better classification of Huntington's Disease and advances in imaging techniques have allowed more precise analysis of its effects on the structural and functional integrity of the visual system. Key changes to the visual system include retinal thinning, reduced VEP amplitude, reduced cell numbers in visual cortex, reduced occipital cortex thickness, impaired colour vision and poor motion perception. However, studies to date typically include small numbers of participants and the direct associations between structural changes to the visual pathway and visual perceptual deficits are relatively unknown. In addition, although changes are evident in HD manifest groups, they are less well-established in pre-manifest gene carriers. Future studies with well-defined HD and HD-related groups in appropriate numbers that systematically examine the relationship between structural changes to pathway, basic visual perceptual deficits and disease stage/severity are therefore likely to yield promising results.

\section{Conflict of interest statement}

The authors have no conflict of interest to report.

\section{References}

[1] Ross CA, Tabrizi, SJ. Huntington's disease: from molecular pathogenesis to clinical treatment. Lancet Neurology. 2011; 10(1): 83.

[2] Roos RAC. Huntington's disease: a clinical review. Orphanet Journal of Rare Diseases. 2011; 5: 40

[3] Schiefer J, Werner CJ, Reetz K. Clinical diagnosis and management in early Huntington's disease: a review. Degenerative Neurological and Neuromuscular Disease. 2015; 5:37. 
[4] Paulsen JS. Cognitive Impairment in Huntington Disease: Diagnosis and Treatment. Curr Neurol Neurosci Rep. 2011; 11:474.

[5] Craufurd D, MacLeod R, Frontali M, Quarrell O, Bijlsma EK Davis M, Hjermind LE, Lahiri N, Mandich P, Martinez A, Tibben A, Roos RA; Working Group on Genetic Counselling and Testing of the European Huntington's Disease Network (EHDN). (2013). Diagnostic genetic testing for Huntington's disease. Practical Neurology. 2013; 15: 80.

[6] Huntington's Study Group. Unified Huntington's Disease Rating Scale: reliability and consistency. Mov Disord. 1996; 11(2):136

[7] Lawrence AD, Watkins LH, Sahakian BJ, Hodges JR, Robbins TW. Visual object and visuospatial cognition in Huntington's disease: implications for information processing in corticostriatal circuits. Brain. 2000; 123, 1349

[8] Labuschagne I, Cassidy AM, Scahill RI, Johnson EB, Rees E, O'Regan A, Queller S, Frost S, Leavitt BR, Dürr A, Roos R, Owen G, Borowsky B, Tabrizi SJ, Stout JC; TRACKHD Investigators. Visuospatial Processing Deficits Linked to Posterior Brain Regions in Premanifest and Early Stage Huntington's Disease. J Int Neuropsychol Soc. 2016; 22:595.

[9] Couette M, Bachoud-Levi AC, Brugieres P, Sieroff E, Bartolomeo P. Orienting of spatial attention in Huntington's Disease. Neuropsychologia. 2008; 46:1391.

[10] Lineweaver TT, Salmon DP, Bondi MW, Corey-Bloom J. Differential effects of Alzheimer's disease and Huntington's disease on the performance of mental rotation. J Int Neuropsychol Soc. 2005; 11:30.

[11] Finke K, Bublak P, Dose M, Müller HJ, Schneider WX. Parameter-based assessment of spatial and non-spatial attentional deficits in Huntington's disease. Brain. 2006; 129, 1137. 
[12] Lasker AG, Zee DS. Ocular motor abnormalities in Huntington's disease. Vision Res. 1997; 37:3639.

[13] Antonnides CA, Kennard C. Ocular abnormalities in neurodegenerative disorders. Eye. 2014; 29(2):200.

[14] Attoni T, Beato R, Pinto S, Cardoso F. Abnormal eye movements in three types of chorea. Arq Neuropsiquiatr. 2016; 74:761.

[15] Moher D, Liberati A, Tetzlaff J, Altman DG; PRISMA Group. Preferred reporting items for systematic reviews and meta-analyses: the PRISMA statement. PLoS Med. 2009; 21;6(7):e1000097.

[16] Paulus W, Schwarz G, Werner A, Lange H, Bayer A, Hofschuster M, Müller N, Zrenner E. Impairment of retinal increment thresholds in Huntington's disease. Ann Neurol. 1993;34(4):574.

[17] Pearl JR, Heath LM, Bergey DE, Kelly JP, Smith C, Laurino MY, Weiss A, Price ND, LaSpada A, Bird TD, Jayadev S. Enhanced retinal responses in Huntington's disease patients. J Huntingtons Dis. 2017; 6(3):237.

[18] Knapp J, VanNasdale DA, Ramsey K, Racine J. Retinal dysfunction in a presymptomatic patient with Huntington's disease. Doc Ophthalmol. 2018;136(3):213.

[19] Ragauskas S, Leinonen H, Puranen J, Rönkkö S, Nymark S, Gurevicius K, Lipponen A, Kontkanen O, Puoliväli J, Tanila H, Kalesnykas G. Early retinal function deficit without prominent morphological changes in the R6/2 mouse model of Huntington's disease. PLoS One. $2014 ; 9(12):$ e113317. 
[20] Bodis-Wollner I, Marx MS, Ghiladri MF. Systemic haloperidol administration increases the amplitude of the light- and dark-adapted flash ERG in the monkey. Clinical Vision Sciences. 1989; 4(1):19.

[21] Kersten HM, Danesh-Meyer HV, Kilfoyle DH, Roxburgh RH.Optical coherence tomography findings in Huntington's disease: a potential biomarker of disease progression. Journal of Neurology. 2015; 262:2457.

[22] Siesling, S., van Vugt, J.P., Zwinderman, K.A., et al. (1998). Unified Huntington's disease rating scale: a follow up. Mov Disord., 13, 915-919.

[23] Andrade C, Beato J, Monteiro A, Costa A, Penas S, Guimarães J, Reis FF, Garrett C. Spectral-Domain Optical Coherence Tomography as a Potential Biomarker in Huntington's Disease. Mov Disord. 2016;31(3):377.

[24] Gulmez Sevim D, Unlu M, Gultekin M, Karaca C. Retinal single-layer analysis with optical coherence tomography shows inner retinal layer thinning in Huntington's disease as a potential biomarker. Int Ophthalmol. 2018 Feb 12. doi: 10.1007/s10792-018-0857-7.

[25] Creel DJ. Visually evoked potentials. In: Webvision: The Organization of the Retina and Visual System [updated 2015 July 14, cited 2018 Nov 20]. Available from: https://webvision.med.utah.edu/book/electrophysiology/visually-evoked-potentials/

[26] Ellenberger C, Petro DJ, Ziegler SB. The visually evoked potential in Huntington disease. Neurology. 1978;28(1):95.

[27] Oepen G, Doerr M, Thoden U.Visual (VEP) and somatosensory (SSEP) evoked potentials in Huntington's chorea. Electroencephalogr Clin Neurophysiol. 1981; 51(6):666.

[28] Josiassen RC, Shagass C, Mancall EL,Roemer RA. Auditory and visual evoked potentials in Huntington's Disease. Electroencephnlogr. Clin. Neurophysiol. 1984; 51:113. 
[29] Lawson EA, Barrett G, Kriss A, Halliday AM. P300 and VEPs in Huntington's Chorea. Annals of the New York Academy of Sciences. 1985; 425:592.

[30] Hennerici M, Hömberg, Lange H. Evoked potentials in patients with Huntington's disease and their offspring. II. Visual evoked potentials. Electroencephalography and clinical neurophysiology. 1985; 62:167.

[31] Holder GE. Electrophysiological assessment of optic nerve disease. Eye. 2004; $18(11): 1133-43$.

[32] Rosas HD, Liu AK, Hersch S, Glessner M, Ferrante RJ, Salat DH, van der Kouwe A, Jenkins BG, Dale AM, Fischl B. Regional and progressive thinning of the cortical ribbon in Huntington's disease. Neurology. 2002; 58(5):695.

[33] Rosas HD, Salat DH, Lee SY, Zaleta AK, Pappu V, Fischl B, Greve D, Hevelone N, Hersch SM. Cerebral cortex and the clinical expression of Huntington's disease: complexity and heterogeneity. Brain. 2008; 131(4):1057-68.

[34] Tabrizi SJ, Reilmann R, Roos R, Durr A, Owen G, Jones R, Johnson H, Craufurd D, Hicks SL, Kennard C, Landwehrmeyer B, Stout JC, Borowsky B, Scahill RI, Frost C, Langbehn DR; TRACK-HD investigators. Potential endpoints for clinical trials in premanifest and early Huntington's disease in the TRACK-HD study: analysis of 24 month observational data. Lancet Neurol. 2012; 11:42.

[35] Johnson EB, Rees EM, Labuschagne I, Durr A, Leavitt BR, Roos RA, Reilmann R, Johnson H, Hobbs NZ, Langbehn DR, Stout JC, Tabrizi SJ, Scahill RI; TRACK-HD investigators. The impact of occipital lobe cortical thickness on cognitive task performance: an investigation in Huntington's disease. Neuropsychologia. 2015; 79:138-46.

[36] Wolf RC, Sambataro F, Vasic N, Baldas EM, Ratheiser I, Bernhard Landwehrmeyer G, Depping MS, Thomann PA, Sprengelmeyer R, Süssmuth SD, Orth M. Visual system integrity and cognition in early Huntington's disease. Eur J Neurosci. 2014; 40(2):2417-26. 
[37] Heinsen H, Strik M, Bauer M, Luther K, Ulmar G, Gangnus D, Jungkunz G,

Eisenmenger W, Götz M. Cortical and striatal neurone number in Huntington's disease. Acta Neuropathol. 1994; 88:320.

[38] Nana AL, Kim EH, Thu DC, Oorschot DE, Tippett LJ, Hogg VM, Synek BJ, Roxburgh R, Waldvogel HJ, Faull RL. Widespread heterogeneous neuronal loss across the cerebral cortex in Huntington's disease. J Huntingtons Dis. 2014;3:45-64.

[39] Rüb U, Seidel K, Vonsattel JP, Lange HW, Eisenmenger W, Götz M. Huntington’s disease (HD): neurodegeneration of Brodmann's Primary Visual Area 17 (BA17). Brain Pathol. 2015; 25(6):701.

[40] Buttner T, Schulz S, Kuhn W, Blumenschein A. Impaired colour discrimination in Huntington's disease. European journal of Neurology. 1994; 1:153.

[41] Parry NRA. Color vision deficiencies. In Handbook of Color Psychology 2015 (Eds. A.J. Elliot, M.D. Fairchild, A. Franklin). Cambridge University Press.

[42] Cranwell MB, Pearce B, Loveridge C, Hurlbert AC. Performance on the FarnsworthMunsell 100-Hue Test Is Significantly Related to Nonverbal IQ. Invest Ophthalmol Vis Sci. 2015;56(5):3171-8.

[43] Robins Wahlin T, Luszcz MA, Wahlin A, Byrne GJ. Non-Verbal and Verbal Fluency in Prodromal Huntington's Disease. Dement Geriatr Cogn Dis Extra. 2015; 5(3): 517-529.

[44] O'Donnell, B.F., Blekher, T.M., Weaver, M. et al. (2008). Visual perception in prediagnostic and early stage Huntington's disease. J Int Neuropsychol Soc., 14, 446-453.

[45] Nasr S, Rosas HD. Impact of Visual Corticostriatal Loop Disruption on Neural Processing within the Parahippocampal Place Area. The Journal of Neuroscience 2016; $36: 10456-10471$.

[46] Owsley, C. (2003). Contrast Sensitivity. Ophthalmol Clin North Am., 16, 171-177. 
[47] Sprengelmeyer, R., Young, A.W., Calder, A.J. et al. (1996). Loss of disgust. Perception of faces and emotions in Huntington's disease. Brain.119, 1647-1665.

[48] Hennenlotter A, Schroeder U, Erhard P, Haslinger B, Stahl R, Weindl A, von Einsiedel HG, Lange KW, Ceballos-Baumann AO. Neural correlates associated with impaired disgust processing in pre-symptomatic Huntington's disease. Brain. 2004; 127(6):1446.

[49] O'Donnell, B.F., Wilt, M.A., Hake, A.M. et al. (2003). Visual function in Huntington's disease patients and presymptomatic gene carriers. Mov Disord., 18, 1027-1034.

[50] Skottun B, Skoyles J. Contrast sensitivity and magnocellular functioning in schizophrenia. Vision Research. 2007; 47:2923.

[51] Born, R.T. \& Bradley, D.C. (2005).Structure and function of visual area MT. Annu Rev Neurosci., 28, 157-189.

[52] Hutchinson CV, Arena A, Allen HA, Ledgeway T. Psychophysical correlates of global motion processing in the aging visual system: a critical review. Neurosci Biobehav Rev. 2012; 36(4):1266.

[53] Born RT, Bradley DC. Structure and function of visual area MT. Annu Rev Neurosci. 2005; 28:157-89.

\section{Figure legends}

Figure 1. A search was undertaken using Web of Science from January 1980 to May 2018, using the following search terms: "Huntington's", 'visual', "vision”, “visual acuity”, “contrast sensitivity", “depth", “stereo", “colour vision”, "form perception”, “motion”, "retina", "visual cortex". Articles were identified in accordance with PRISMA guidelines [after Moher et al., 15]. 38 full text articles were screened of which 26 were included in the review. 
Fig. 1

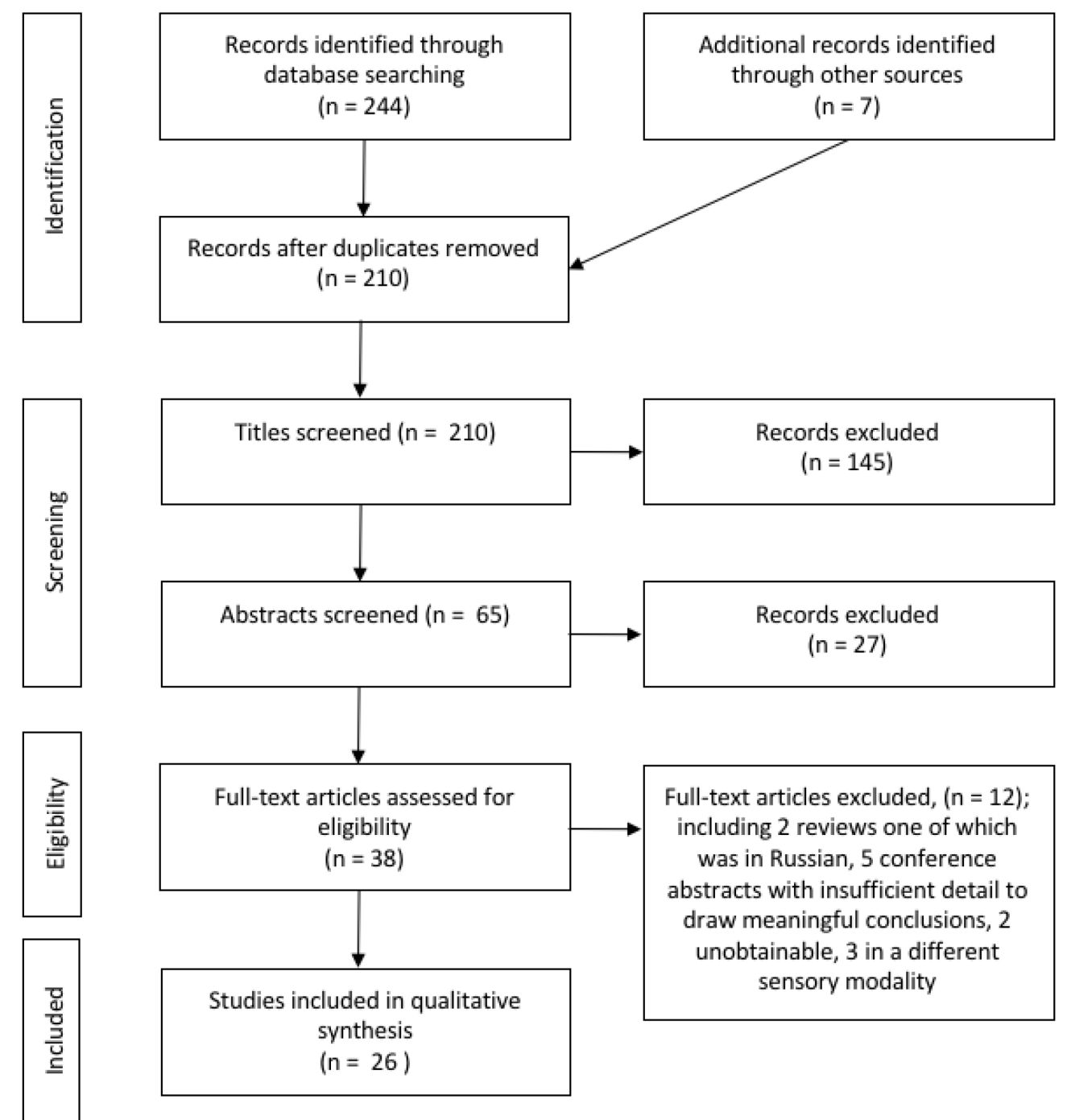


Table 1. Summary of retinal findings in Huntington's Disease

\begin{tabular}{|c|c|c|c|}
\hline Authors & Participant groups & Technique & Main findings \\
\hline $\begin{array}{l}\text { Paulus et al. } \\
(1993)\end{array}$ & $\begin{array}{l}19 \text { HD patients } \\
61 \text { controls }\end{array}$ & Maxwellian View System & $\begin{array}{l}\text { - Higher increment detection thresholds for a foveal blue test in } \\
\text { HD group }\end{array}$ \\
\hline $\begin{array}{l}\text { Pearl et al. } \\
(2017)\end{array}$ & $\begin{array}{l}18 \text { HD patients } \\
10 \text { controls }\end{array}$ & Electroretinogram (ERG) & $\begin{array}{l}\text { - Increased ERG amplitudes in HD group } \\
\text { - No differences in latencies }\end{array}$ \\
\hline \multirow[t]{3}{*}{$\begin{array}{l}\text { Knapp et al. } \\
\text { (2018) }\end{array}$} & \multirow{3}{*}{$\begin{array}{l}1 \text { asymptomatic HD } \\
\text { gene carrier } \\
19 \text { controls }\end{array}$} & Electroretinogram (ERG) & $\begin{array}{l}\text { - } \text { Reduced ERG amplitudes in HD gene carrier } \\
\text { - No differences in latencies }\end{array}$ \\
\hline & & $\begin{array}{l}\text { Multifocal Electroretinogram } \\
\text { (mfERG) }\end{array}$ & $\begin{array}{l}\text { - } \quad \text { Reduced P1 amplitudes in HD gene carrier } \\
\text { - } \quad \text { No differences in latencies }\end{array}$ \\
\hline & & $\begin{array}{l}\text { Optical Coherence } \\
\text { Tomography (OCT) }\end{array}$ & - No differences in the macular retina \\
\hline $\begin{array}{l}\text { Kersten et al. } \\
(2015)\end{array}$ & $\begin{array}{l}20 \text { eyes of } 20 \mathrm{HD} \\
\text { patients } \\
6 \text { eyes of } 6 \text { pre- } \\
\text { manifest HD } \\
29 \text { eyes of } 29 \\
\text { controls }\end{array}$ & $\begin{array}{l}\text { Optical Coherence } \\
\text { Tomography (OCT) }\end{array}$ & $\begin{array}{l}\text { - No differences in average, nasal, superior or inferior } \\
\text { peripapillary RNFL thickness } \\
\text { - Temporal RNFL thickness reduced in HD group } \\
\text { - No differences in total macular volume or macular thickness } \\
\text { - Disease duration was negatively associated with temporal RNFL } \\
\text { thickness (when premanifest individuals were removed from the } \\
\text { analysis) and macular volume; Motor scores were negatively } \\
\text { associated with macular volume. }\end{array}$ \\
\hline $\begin{array}{l}\text { Andrade et al. } \\
\text { (2016) }\end{array}$ & $\begin{array}{l}15 \text { eyes of } 8 \mathrm{HD} \\
\text { patients } \\
16 \text { eyes of } 8 \text { controls }\end{array}$ & $\begin{array}{l}\text { Optical Coherence } \\
\text { Tomography (OCT) }\end{array}$ & $\begin{array}{l}\text { - } \\
\text { - No differences in peripapillary RNFL thickness } \\
\text { - No differences in choroid thickness } \\
\text { - Average, central and inferior macular choroidal thickness } \\
\text { reduced in HD patients. Temporal, nasal, superior macular } \\
\text { choroidal thickness reduction approached significance } \\
\text { - TMS-UHDRS scores were negatively associated with average, } \\
\text { nasal, superior and macular retinal thickness }\end{array}$ \\
\hline $\begin{array}{l}\text { Gulmez Sevim } \\
\text { et al., (2018) }\end{array}$ & $\begin{array}{l}15 \text { eyes of HD } \\
\text { patients* }\end{array}$ & $\begin{array}{l}\text { Optical Coherence } \\
\text { Tomography (OCT) }\end{array}$ & $\begin{array}{l}\text { No differences in average, nasal, inferonasal or superonasal } \\
\text { peripapillary RNFL thickness }\end{array}$ \\
\hline
\end{tabular}




\begin{tabular}{|ll|}
\hline 15 eyes of controls & $\bullet \begin{array}{l}\text { Temporal, inferotemporal and superotemporal RNFL thickness } \\
\text { reduced in HD group }\end{array}$ \\
& $\bullet \begin{array}{l}\text { Outer nuclear and outer retinal layers were thicker in HD } \\
\text { patients. }\end{array}$ \\
& $\bullet \begin{array}{l}\text { Inner plexiform layer, retinal pigment epithelium and outer } \\
\text { macular volume were lower in HD group }\end{array}$ \\
\hline
\end{tabular}

RNFL: retinal nerve fibre layer

*Note that in the Gulmez Sevim et al., (2018), the text states that 15 eyes of 15 patients and 15 eyes of healthy controls were included. However, in Tables 1,2 and 4, $n=30$ is given for patients and controls, which suggests that both eyes were included in the analysis. We have reported the group numbers stated explicitly the text, rather than that from the data tables in the paper. 
Table 2. Summary of visual evoked potential (VEP) studies in Huntington's Disease

\begin{tabular}{|c|c|c|c|}
\hline Study & Participants & VEP Amplitude & VEP Latency \\
\hline $\begin{array}{l}\text { Ellenberger et al. } \\
\text { (1978) }\end{array}$ & $\begin{array}{l}18 \text { HD patients } \\
13 \text { at risk offspring } \\
50 \text { controls }\end{array}$ & $\begin{array}{l}\text { Reduced in HD group } \\
\text { Normal in offspring }\end{array}$ & $\begin{array}{l}\text { No differences } \\
\text { between groups }\end{array}$ \\
\hline Oepen et al. (1981) & $\begin{array}{l}13 \text { HD patients } \\
9 \text { at risk offspring } \\
40 \text { controls }\end{array}$ & $\begin{array}{l}\text { Reduced in HD group } \\
\text { Reduced in } 4 \text { offspring }\end{array}$ & $\begin{array}{l}\text { No differences } \\
\text { between groups }\end{array}$ \\
\hline $\begin{array}{l}\text { Josiassen et al. } \\
\text { (1984) }\end{array}$ & $\begin{array}{l}21 \text { HD patients } \\
21 \text { controls }\end{array}$ & Reduced in HD group & $\begin{array}{l}\text { No differences } \\
\text { between groups }\end{array}$ \\
\hline $\begin{array}{l}\text { Lawson et al. } \\
\text { (1984) }\end{array}$ & $\begin{array}{l}13 \text { HD patients } \\
18 \text { at risk offspring } \\
15 \text { Controls }\end{array}$ & $\begin{array}{l}\text { Reduced in HD group } \\
\text { No difference between } \\
\text { HD group and } \\
\text { offspring }\end{array}$ & $\begin{array}{l}\text { No differences } \\
\text { between groups }\end{array}$ \\
\hline $\begin{array}{l}\text { Hennerici et al. } \\
\text { (1985) }\end{array}$ & $\begin{array}{l}36 \text { HD patients, } 36 \\
\text { controls } \\
55 \text { at risk offspring, } \\
55 \text { controls }\end{array}$ & $\begin{array}{l}\text { Reduced in HD group } \\
\text { and offspring }\end{array}$ & $\begin{array}{l}\text { No differences } \\
\text { between groups }\end{array}$ \\
\hline
\end{tabular}


Table 3. Summary of visual sensitivity deficits in Huntington's Disease

\begin{tabular}{|c|c|c|c|}
\hline & Authors & Participant groups & Main findings \\
\hline \multirow[t]{3}{*}{ Colour vision } & $\begin{array}{l}\text { Buttner et al., } \\
\text { (1994) }\end{array}$ & $\begin{array}{l}16 \text { HD patients } \\
18 \text { controls }\end{array}$ & $\begin{array}{l}\text { HD group exhibited poorer colour discrimination scores } \\
\text { on FM-100 Hue Test, particularly on red-green and blue- } \\
\text { yellow axes }\end{array}$ \\
\hline & $\begin{array}{l}\text { Kersten et al., } \\
(2015)\end{array}$ & $\begin{array}{l}26 \text { HD group ( } 20 \text { manifest HD }+6 \text { pre- } \\
\text { manifest HD) } \\
29 \text { controls }\end{array}$ & $\begin{array}{l}\text { - HD group performed significantly worse on the Ishihara } \\
\text { Colour Vision Plates. } \\
\text { - } 50 \% \text { of the HD group misidentified at least one plate (out } \\
\text { of a maximum of 14). } \\
\text { - Performance did not differ between manifest and pre- } \\
\text { manifest groups. } \\
\text { - Pre-manifest HD and controls were not compared directly, } \\
\text { although it is unlikely that they differed significantly, } \\
\text { given group performance (Pre-manifest HD: } 13.38 / 14 \\
\text { (0.41 SD); Controls: } 13.97 / 14 \text { (0.91 SD), from Kersten et } \\
\text { al. 2015; Table 1). }\end{array}$ \\
\hline & $\begin{array}{l}\text { Sevim et al., } \\
(2018)\end{array}$ & $\begin{array}{l}15 \text { HD patients } \\
15 \text { controls }\end{array}$ & $\begin{array}{l}\text { HD group misidentified significantly more plates on the } \\
\text { Ishihara Colour Vision Plates }\end{array}$ \\
\hline \multirow[t]{2}{*}{$\begin{array}{l}\text { Form } \\
\text { perception }\end{array}$} & $\begin{array}{l}\text { O’Donnell et al. } \\
\text { (2008) }\end{array}$ & $\begin{array}{l}36 \text { HD patients (HD) } \\
32 \text { pre-diagnostic gene carriers with } \\
\text { moderate neurological abnormalities (PD2) } \\
20 \text { pre-diagnostic gene carriers with mild } \\
\text { neurological abnormalities (PD1) } \\
201 \text { controls }\end{array}$ & $\begin{array}{l}\text { - No differences between groups for distinguishing between } \\
\text { a circle and a square embedded in visual noise }\end{array}$ \\
\hline & $\begin{array}{l}\text { Nasr \& Rosas } \\
(2016)\end{array}$ & $\begin{array}{l}12 \text { HD patients } \\
12 \text { controls }\end{array}$ & $\begin{array}{l}\text { - HD patients were worse at distinguishing between a circle } \\
\text { and a triangle embedded in visual noise }\end{array}$ \\
\hline \multirow[t]{2}{*}{$\begin{array}{l}\text { Spatial } \\
\text { Contrast } \\
\text { Sensitivity }\end{array}$} & $\begin{array}{l}\text { Spengelmeyer et } \\
\text { al. (1996) }\end{array}$ & $\begin{array}{l}13 \text { HD patients } \\
17 \text { controls }\end{array}$ & $\begin{array}{l}\text { - No differences between groups on VISTECH Contrast } \\
\text { Sensitivity Test, except for highest spatial frequency (18 } \\
\text { c/deg) for which HD group performed better }\end{array}$ \\
\hline & $\begin{array}{l}\text { Hennenlotter et al. } \\
(2004)\end{array}$ & $\begin{array}{l}9 \text { pre-symptomatic gene carriers } \\
9 \text { controls }\end{array}$ & $\begin{array}{l}\text { - No differences between groups on VISTECH Contrast } \\
\text { Sensitivity Test. }\end{array}$ \\
\hline
\end{tabular}




\begin{tabular}{|c|c|c|c|}
\hline & $\begin{array}{l}\text { O’Donnell et al. } \\
\text { (2003) }\end{array}$ & $\begin{array}{l}9 \text { HD patients } \\
9 \text { pre-symptomatic gene carriers } \\
20 \text { controls }\end{array}$ & $\begin{array}{l}\text { - No differences between groups for detecting stationary } \\
\text { sinusoidal gratings }(0.53,2.13,10.5 \mathrm{c} / \mathrm{deg})\end{array}$ \\
\hline & $\begin{array}{l}\text { O'Donnell et al. } \\
\text { (2008) }\end{array}$ & $\begin{array}{l}36 \text { HD patients (HD) } \\
32 \text { pre-diagnostic gene carriers with } \\
\text { moderate neurological abnormalities (PD2) } \\
20 \text { pre-diagnostic gene carriers with mild } \\
\text { neurological abnormalities (PD1) } \\
201 \text { controls }\end{array}$ & $\begin{array}{l}\text { - No differences between groups for detecting stationary } \\
\text { sinusoidal grating }(9.9 \mathrm{c} / \mathrm{deg})\end{array}$ \\
\hline $\begin{array}{l}\text { Temporal } \\
\text { Contrast } \\
\text { Sensitivity }\end{array}$ & $\begin{array}{l}\text { O’Donnell et al. } \\
\text { (2008) }\end{array}$ & $\begin{array}{l}36 \text { HD patients (HD) } \\
32 \text { pre-diagnostic gene carriers with } \\
\text { moderate neurological abnormalities (PD2) } \\
20 \text { pre-diagnostic gene carriers with mild } \\
\text { neurological abnormalities (PD1) } \\
201 \text { controls }\end{array}$ & $\begin{array}{l}\text { HD group had poorer contrast sensitivity compared PD1 } \\
\text { group and controls at all temporal frequencies }(2.1,9.3 \text {, } \\
18.8 \mathrm{~Hz}) \\
\text { - HD group exhibited poorer contrast sensitivity compared } \\
\text { to PD2 group at } 2.1 \mathrm{~Hz} \\
\text { - } \mathrm{PD} 2 \text { group exhibited poorer contrast sensitivity compared } \\
\text { to PD1 group and controls at } 9.3 \mathrm{~Hz}\end{array}$ \\
\hline \multirow[t]{2}{*}{$\begin{array}{l}\text { Global motion } \\
\text { perception }\end{array}$} & $\begin{array}{l}\text { O’Donnell et al. } \\
\text { (2003) }\end{array}$ & $\begin{array}{l}9 \text { HD patients } \\
9 \text { pre-symptomatic gene carriers } \\
20 \text { controls }\end{array}$ & $\begin{array}{l}\text { HD group were more susceptible to visual noise (had } \\
\text { lower noise thresholds) than controls when required to } \\
\text { discern the direction of signal dots embedded in noise dots } \\
\text { - No differences between pre-symptomatic gene carriers } \\
\text { and controls } \\
\text { - Statistical comparison between HD group and pre- } \\
\text { symptomatic gene carrier task performance is not provided }\end{array}$ \\
\hline & $\begin{array}{l}\text { O'Donnell et al. } \\
\text { (2008) }\end{array}$ & $\begin{array}{l}36 \text { HD patients (HD) } \\
32 \text { pre-diagnostic gene carriers with } \\
\text { moderate neurological abnormalities (PD2) } \\
20 \text { pre-diagnostic gene carriers with mild } \\
\text { neurological abnormalities (PD1) } \\
201 \text { controls }\end{array}$ & $\begin{array}{l}\text { - No differences between groups for discerning the direction } \\
\text { of signal dots embedded in noise dots }\end{array}$ \\
\hline
\end{tabular}

